\title{
Dissection of function and recognition mechanism of M. tuberculosis ESX-1 secreted virulence factor EspC
}

Ruby Sharma ${ }^{1 *}$, Vipin K. Kashyap ${ }^{1 *}$, Manoj Kumar ${ }^{2}$, Abhisheka Bansal ${ }^{2}$ and Ajay K. Saxena ${ }^{1} \#$

${ }^{1} \mathrm{Rm}-403 / 440$, Structural Biology Lab, School of Life Sciences, Jawaharlal Nehru University, New Delhi-67, India

${ }^{2}$ Rm-111, Molecular Parasitology Lab, School of Life Sciences, Jawaharlal Nehru University, New Delhi-67, India

* Equal contributions

Running Title: Function and recognition mechanism of $M t b E s p C$

\#Corresponding author: Ajay K. Saxena, Rm-403/440, Structural Biology Lab, School of Life Sciences, Jawaharlal Nehru University, New Delhi-67, India. Phone:011- 26704155, Email:ajaysaxena@mail.jnu.ac.in 


\begin{abstract}
Mycobacterium tuberculosis uses the ESAT-6 system-1/type VII (ESX-1) system for secretion of virulence proteins into the host cell, however the mechanism of virulence proteins secretion, molecular components and regulation of ESX-1 system are only partly understood. In the current study, we have analyzed the biological function and recognition mechanism between ESX-1 virulence EspC and $\mathrm{EccA}_{1}$ ATPase proteins. The EspC enters into A549 human lung carcinoma cells and exhibited cytotoxicity, as observed in MTT Assay. To understand the recognition mechanism between EspC and $\mathrm{EccA}_{1}$ ATPase, the EspC and Ecc $\mathrm{A}_{1}$ mutants were generated based on EspC $\sim \mathrm{EccA}_{1}$ interactions, as observed in molecular modeling. Binding analysis shows that EspC export arm interacts specifically to the $\beta$-hairpin insertion motif of the TPR domain of Ecc $_{1}$ ATPase. Mutations in these epitopes lead to significant decrease/or abolish the binding between EspC and $\operatorname{EccA}_{1}$ ATPase. Our study provides insight into biological function and recognition mechanism between $\mathrm{EspC}$ and $\mathrm{EccA}_{1}$ ATPase, which can be used as target to prevent EspC secretion/ or in general virulence factor secretion by mycobacterial ESX-1 system.
\end{abstract}

Keywords: Mycobacterium tuberculosis, ESX-1 secretion system, EspC virulence protein, Ecc $_{1}$ ATPase, Functional analysis, Recognition mechanism 
Mycobacterium tuberculosis ESX-1 secretion system is involved in essential pathogenesis, e.g., host phagosomal permeabilization, mycobacterial escape to cytosol and macrophage killing [15]. The ESX-1 secretion system exports the virulence proteins across the lipid-rich cell wall and helps in the permeabilization of host macrophage phagosomal membrane. The ESX-1 virulence proteins are involved in pore-formation in the membrane, modulation of extracellular signaling pathway [6-10] and act as a structural component of extracellular region of secretion apparatus itself [11]. The RD1 (region of difference) genes and its surrounding regions e.g., extended RD1 $[12,13]$ in $M$. tuberculosis and M. marinum encode virulence proteins of the ESX-1 secretion system. The EspC $(R v 3615 c)$ gene is encoded in the extended RD1 locus and is also present in Bacillus Calmette-Guérin vaccine [14]. The EspC is highly immunodominant like ESAT-6 and CFP-10 proteins in latent and active tuberculosis infections [15]. The EspC is upregulated at low $\mathrm{pH}[16]$ and in low iron conditions [17], as observed in vitro transcriptional response study. In a recent study [18], the EspC is found co-precipitate with EspA in both cytosolic and membrane fraction of M. tuberculosis cells. The EspC exists as cluster or long filament [18] and C-terminal region of $\mathrm{EspC}$ is involved in the polymer formation, which causes the mycobacterial virulence.

Mechanism of EspC secretion and its involvement in the regulation of ESX-1 system is currently unknown. The ESX-1 virulence proteins contain general "secretion signal", which targets the $\mathrm{AAA}^{+}$ATPase before exporting across the mycobacterial inner membranes [19, 20]. The structure of "secretion signal" is identified in the crystal structures of M.tuberculosis ESAT6/CFP-10 complex [21-25] and EspB protein [26]. The nuclear magnetic resonance [27], X-ray crystallographic [21, 22, 24] and yeast two-hybrid [19] studies have shown that export arm of virulence proteins are stabilized by interaction with $\mathrm{AAA}^{+}$ATPase [30], a key phase in the export cycle and a potential determinant of substrate specificity. Recently, the crystal structure of Thermonospora curvata EccC enzyme in complex with signal sequence of Thermonospora 
curvata EsxB had been determined [28]. In this structure, the C-terminal signal sequence of $T$. curvata EsxB (96-103 residues) forms a short amphiphatic helix that interacts with hydrophobic pocket of $\mathrm{ATPase}_{3}$ domain of T. curvata EccC enzyme. However, YxxxD secretion motif of EsxB signal peptide was found disordered in the crystal structure and appeared not involved in EccC recognition [28].

The EspC recognizes the Ecc $\mathrm{A}_{1}$ ATPase $(R v 3868,573$ residues, $\mathrm{Mw} \sim 67 \mathrm{kD})$, an essential component of ESX-1 secretion system and is involved in mycobacterial survival and virulence proteins secretion [29]. The EccA $\mathrm{A}_{1}$ ATPase mutants bind several enzymes involved in cell wall biogenesis and prevent mycolic acid synthesis [29]. The Ecc $\mathrm{A}_{1}$ ATPase contains N-terminal tetratricopeptide repeat (TPR) domain involved in ESX-1 virulence proteins recognition and the C-terminal ATPase domain involved in ATP hydrolysis [30]. The crystal structure of TPR domain of Ecc $\mathrm{A}_{1}$ has been determined (PDB-4F3V), which adopts a TPR like fold as observed in other TPR domain proteins [31]. Swapping of C-terminal region of EspC with CFP-10 impairs the EspC secretion by ESX-1 system, as EccC ATPase recognizes only the CFP-10 export arm [30].

Yeast two hybrid and genetic studies have been performed to understand the ESX-1 virulence proteins recognition by their targets. In a recent structural study on $T$. curvata EccC enzyme in complex with signal sequence of T. curvata EsxB [28] showed that signal sequence of T. curvata EsxB forms short amphipathic helix and binds to hydrophobic pocket observed at Cterminal of $\mathrm{ATPase}_{3}$ domain of EccC enzyme, which resulted in enhanced ATPase activity. Molecular basis of EspC recognition by Ecc $\mathrm{A}_{1}$ ATPase is currently unknown. It will be highly important to understand, how EspC export arm recognizes the TPR domain of EccA $\mathrm{A}_{1}$ ATPase and interacting residues involved in binding between EspC and $\mathrm{EccA}_{1}$, as observed by Rosenberg et. al. [28].

In current study, we have purified and performed functional studies on $M$. tuberculosis 
EspC and Ecc $\mathrm{A}_{1}$ ATPase. To understand the mechanism of EspC $\sim \mathrm{Ecc} \mathrm{A}_{1}$ recognition, we built the EspC $\sim \mathrm{EccA}_{1}$ complex model and interactions involved in EspC $\sim \mathrm{EccA}_{1}$ recognition were identified. The EspC and EccA 1 mutants were generated based on these interactions and binding analysis was performed using wild type and mutant EspC and Ecc $\mathrm{A}_{1}$ proteins. CD spectroscopy was performed to analyze the conformation and stability of the wild type and mutant EspC and Ecc $\mathrm{A}_{1}$ proteins. Our study shows the biological activities and molecular mechanism involved in the $\mathrm{EspC} \sim \mathrm{EccA}_{1}$ recognition, which is essential for EspC secretion by the ESX-1 secretion system.

\section{MATERIALS AND METHODS}

Chemicals and Reagents: All the reagents, of analytical grade were procured from SigmaAldrich.

Preparation of wild type and mutant EspC proteins. The EspC gene encoding Met1Thr103 residues was amplified from $M$. tuberculosis $H 37 R v$ strain and cloned into $p E T 21 a(+)$ vector. The EspC plasmid was transformed in E. coli. BL21(DE3) cells and culture was grown at $37^{\circ} \mathrm{C}$ in Luria Bertani media supplemented with $100 \mu \mathrm{g} / \mathrm{ml}$ ampicillin. The culture was grown till $\mathrm{OD}_{600} \sim 0.6-0.7$ and induced with $1 \mathrm{mM}$ IPTG at $37^{\circ} \mathrm{C}$. After induction, cells were grown for another $4 \mathrm{~h}$ and harvested by centrifugation at 16,000xg. The cell pellet was suspended in lysis buffer containing (20mM HEPES pH 7.5, 50mM NaCl, 5\% glycerol, 4mM $\beta$-mercaptoethanol, $1 \mathrm{mM}$ phenylmethylsulfonylfluoride, $0.01 \%(\mathrm{w} / \mathrm{v})$ Tween-20 and $0.01 \%(\mathrm{w} / \mathrm{v})$ SDS $)$ and disrupted by sonication. The disrupted lysate was centrifuged at 25000x g and supernatant was collected.

The supernatant was mixed with pre-equilibrated Ni-NTA resin (Sigma) and incubated for $1 \mathrm{~h}$ on $360^{\circ}$ rocker at $4^{\circ} \mathrm{C}$. The protein was loaded in an empty column and washed with buffer containing (20mM HEPES pH 7.5, 50mM NaCl, 5\% Glycerol, 4mM $\beta$-mercaptoethanol, 
$1 \mathrm{mM}$ Phenylmethylsulfonyl fluoride, $0.01 \%(\mathrm{w} / \mathrm{v})$ Tween-20, 0.01\%(w/v) SDS and 10mM imidazole). The EspC was eluted in a buffer containing (20mM HEPES pH 7.5, 50mM NaCl, 5\% Glycerol, 3mM $\beta$-mercaptoethanol, 1mM Phenylmethylsulfonyl fluoride, 0.01\%(w/v) Tween-20, $0.01 \%(\mathrm{w} / \mathrm{v})$ SDS, $100 \mathrm{mM}$ imidazole). The eluted fractions of EspC were concentrated and loaded on Superdex ${ }^{\mathrm{TM}} 200$ HiLoad (16/60) column (GE Healthcare). The column was pre-equilibrated with buffer containing (20mM HEPES pH 7.5, 50mM NaCl, 5mM $\beta$-mercaptoethanol, $0.01 \%(\mathrm{w} / \mathrm{v})$ Tween-20, $0.01 \%(\mathrm{w} / \mathrm{v})$ SDS]. The peak fractions from size exclusion column were pooled and concentrated using $3 \mathrm{kD}$ cutoff ultracentrifugal device (Millipore, USA). The EspC purity was checked on 12\% SDS-PAGE and by mass spectrometry. The EspC concentration was measured using absorbance at $280 \mathrm{~nm}$. The purified recombinant EspC contains 112 residues, $\mathrm{Mw} \sim 11.9 \mathrm{kD}$ (extra Met residue at N-terminal, 103 residues of EspC and LEHHHHHH residues at C-terminal).

Two point mutants of EspC (EspC-D91A and EspC-Y89A) were generated using site directed mutagenesis technique and all mutants were confirmed by DNA sequencing. The EspC$\Delta 5$, EspC- $\Delta 10$ and EspC- $\Delta 20$ truncated mutants were obtained using PCR based mutagenesis protocol and confirmed by gene sequencing. The wild type EspC plasmid was used as template for mutant PCR amplification. The amplified plasmid was incubated with DpnI enzyme for $1 \mathrm{~h}$ at $37^{\circ} \mathrm{C}$ and mutant plasmids were isolated using DH5 $\alpha$ cell. All five EspC mutants were purified using the same protocol used for wild type EspC.

MTT assay to examine the EspC cytotoxicity on A549 cells. The MTT assay was performed to evaluate the EspC cytotoxicity in human lung carcinoma A549 cells. The MTT assay detects the reduction of MTT [3-(4,5-dimethylthiazolyl)-2,5-diphenyl-tetrazolium bromide) by mitochondrial dehydrogenases, which forms the formazan product. The reaction 
gives the blue color, which measures the cytotoxicity or cell viability. The A549 cells were seeded in 96-well plates at a density of $15 \times 10^{4}$ cells/well for $24 \mathrm{~h}$. Afterwards, these cells were treated with EspC for various time points e.g., 2 h, 4 h, 6 h, 12 h and 24 h. After the treatment, $100 \mu \mathrm{l}$ of MTT (total=2.5 mg) was added in each well containing A549 cells and was incubated at $37^{\circ} \mathrm{C}$ for $4 \mathrm{~h}$. After incubation, the media was carefully aspirated from the wells and formazan crystals obtained in the wells were dissolved in $100 \mu \mathrm{l}$ of DMSO. The solution was kept on shaker for $15 \mathrm{~min}$ to dissolve the entire crystals. All steps were performed under proper protection from light. The microplate reader (ThermoFisher Scientific multiplate reader) was used to measure the absorbance at wavelength $570 \mathrm{~nm}$. The live cells were counted under an inverted phase contrast microscope in hematocytometer with 10X magnification.

Confocal microscopy analysis. For confocal microscopy, the A549 cells were grown on coverslip and were washed three times with PBS buffer. Freshly prepared fixing solution (1\% acetone in chilled Methanol) was added and incubated for 20 min at $4^{\circ} \mathrm{C}$. The A549 cells were washed three times with PBS buffer for $3 \mathrm{~min}$. The cells were permeabilized in PBS buffer (containing in $0.1 \%$ Triton $\mathrm{X}-100$ ) for $5 \mathrm{~min}$ at room temperature. The cells were further washed three times with PBS buffer and blocked with 5\% skimmed milk prepared in PBST buffer for $2 \mathrm{~h}$. The cells were incubated with anti-His antibody (1:200 dilution) for $1 \mathrm{~h}$ followed by washing three times with PBS buffer for 5 min. FITC conjugated mouse secondary antibody (GeNei Laboratories, India) was then added (1:1000 dilution) and incubated for $1 \mathrm{~h}$. The cells were again washed three times with PBS buffer for $5 \mathrm{~min} .11$ of DAPI $(1 \mu \mathrm{g} / \mathrm{ml}$ in PBST buffer) solution was added in the well and incubated for $10 \mathrm{~min}$. The A549 cells were washed three times with PBST buffer for $5 \mathrm{~min}$. Slides were labeled and a small drop of mounting agent (50\% Glycerol in 1xPBS buffer) was added to it. Coverslip containing cells were kept upside 
down on mounting agent over the slide. The coverslip was then sealed with the nail paint. The slides were examined under confocal microscopy. Stained cells were imaged using Nikon confocal microscope at Central Instrumentation Facility (CIF) of Jawaharlal Nehru University.

Western Blot analysis. To test the amount of EspC protein present in the A549 cells, we have performed the Western blot analysis. The A549 cells were treated with EspC protein (conc. $\sim 100$ $\mu \mathrm{g} / \mathrm{ml}$ ) for 2,4 , and $6 \mathrm{~h}$. The treated cells were placed on ice and then washed with ice-cold PBS buffer. $70 \mu \mathrm{l}$ of ice-cold lysis buffer (50mM Tris-HCl, pH 7.4, 150mM NaCl, 1mM EDTA, 1\% Triton-X100, 0.1\% SDS, 1mM PMSF, 1X proteinase inhibitor cocktail, 10\% Glycerol) was added in it, followed by centrifugation at $12,000 \mathrm{x}$ g for $20 \mathrm{~min}$ at $4^{\circ} \mathrm{C}$. The supernatant was used for protein analysis by western blotting. The total amount of protein was estimated by Bradford assay. Total $80 \mu \mathrm{g}$ protein was used for Western blot analysis.

The proteins were separated on SDS-PAGE and transferred on a PVDF membrane. The membrane was blocked for $1 \mathrm{~h}$ at room temperature using the 5\% skimmed milk in TBST buffer. The membrane was incubated with anti-His antibody (1:2000 dilution) in $2.5 \%$ BSA in TBST buffer for overnight at $4^{\circ} \mathrm{C}$. The membrane was washed three times with TBST buffer, $5 \mathrm{~min}$ each followed by incubation with HRP conjugated mouse secondary antibody (GeNei Laboratories, 1:2000 dilution) in 5\% skimmed milk in TBST buffer at room temperature for $1 \mathrm{~h}$. The membrane was further washed three times with TBST buffer for 5 min each. The membrane was developed using Luminata Forte (Merck Millipore, USA) followed by exposure on X-ray film.

Preparation of wild type and mutant EccA 1 proteins. The $\mathrm{EccA}_{1}$ gene encoding (Met1Glu573) was amplified using $M$. tuberculosis $H 37 R v$ strain and cloned into pET23a (+) 
expression vector. The EccA 1 plasmid was transformed into E. coli BL21(DE3) cells and culture was grown at $37^{\circ} \mathrm{C}$ in Luria Bertani media supplemented with $100 \mu \mathrm{g} / \mathrm{ml}$ ampicillin at $37^{\circ} \mathrm{C}$, till $\mathrm{OD}_{600}$ reached to $0.6-0.7$. The culture was induced with $0.5 \mathrm{mM}$ IPTG at $22^{\circ} \mathrm{C}$ and grown further for another $10 \mathrm{~h}$. The EccA 1 was overexpressed in soluble fraction of cell. The cells were harvested by centrifugation at $16,000 \mathrm{x} \mathrm{g}$ and suspended in lysis buffer containing (20mM HEPES pH 7.5, 150mM NaCl, 5\% Glycerol, $4 \mathrm{mM} \quad \beta$-mercaptoethanol, $1 \mathrm{mM}$ Phenylmethylsulfonyl fluoride, $4 \mathrm{mM}$ Benzamidine-hexachloride, $0.2 \mathrm{mM} \mathrm{MgCl} 2,0.2 \mathrm{mM}$ ATP, $10 \mathrm{mM}$ Arginine and $0.2 \mathrm{mg} / \mathrm{ml}$ Lysozyme). The cell lysate was centrifuged at 25,000 x $\mathrm{g}$ and supernatant was collected.

The supernatant was mixed with pre-equilibrated Ni-NTA resin (Sigma) and incubated 1 h at $360^{\circ}$ rocker at $4{ }^{\circ} \mathrm{C}$. The Ni-NTA column was washed with buffer containing $(20 \mathrm{mM}$ HEPES pH 7.5, 150mM NaCl, 5\% Glycerol, 4mM $\beta$-mercaptoethanol, 1mM Phenylmethylsulfonylfluoride, $3 \mathrm{mM}$ Benzamidinehexachloride, $10 \mathrm{mM}$ Arginine, $0.2 \mathrm{mM} \mathrm{MgCl}$, $0.2 \mathrm{mM}$ ATP and $40 \mathrm{mM}$ imidazole). The EccA $\mathrm{A}_{1}$ was eluted in buffer containing (20mM HEPES pH 7.5, $150 \mathrm{mM} \mathrm{NaCl}, 5 \%$ glycerol, 4mM $\beta$-mercaptoethanol, 1mM Phenylmethylsulfonyl fluoride, $3 \mathrm{mM}$ Benzamidine hydrochloride, $10 \mathrm{mM}$ Arginine, $0.2 \mathrm{mM} \mathrm{MgCl}_{2}, 0.2 \mathrm{mM}$ ATP, and $250 \mathrm{mM}$ imidazole). The Ni-NTA eluted fractions were pooled, concentrated and loaded on Superdex ${ }^{\mathrm{TM}} 200$ HiLoad (16/60) column (GE Healthcare). The column was pre-equilibrated with buffer containing $(20 \mathrm{mM}$ HEPES $\mathrm{pH} \quad 7.5, \quad 150 \mathrm{mM} \quad \mathrm{NaCl}, \quad 5 \%$ Glycerol, $1 \mathrm{mM}$ Phenylmethylsulfonyl fluoride, $10 \mathrm{mM}$ Arginine, $0.2 \mathrm{mM} \mathrm{MgCl}_{2}, 0.2 \mathrm{mM}$ ATP, $4 \mathrm{mM} \beta$ mercaptoethanol). The peak fractions were pooled and concentrated using a $30 \mathrm{kD}$ cutoff ultracentrifugal device (Millipore, USA). The purity of EccA ${ }_{1}$ was analyzed on $12 \%$ SDS-PAGE and mass spectrometry. The concentration of protein was measured by absorbance at $280 \mathrm{~nm}$. 
Two Ecc $\mathrm{A}_{1}$ mutants, W94A and Y87A were obtained using site directed mutagenesis technique. Wild type EccA 1 plasmid encoding (Met1-Glu573 residues) was used as template for PCR amplification. The amplified EccA 1 plasmid was digested with DpnI enzyme for $1 \mathrm{~h}$ at 37 ${ }^{\circ} \mathrm{C}$. The digested EccA 1 plasmid was transformed in $\mathrm{DH}_{5} \alpha$ cells and both Ecc $\mathrm{A}_{1}$ mutants W94A and Y87A plasmids were isolated. The EccA $A_{1}$ mutant proteins were purified using the same protocol used for wild type EccA $\mathrm{A}_{1}$ purification.

Ecc $_{1}$ ATPase activity analysis. To analyze the ATPase activity, the Ecc $\mathrm{A}_{1}$ was dissolved in ATPase buffer containing 20mM HEPES pH 7.5, 5mM $\mathrm{MgCl}_{2} .1 \mu \mathrm{l}$ of $\left(\gamma^{32 \mathrm{P}}\right)$ ATP $\left(0.1 \mathrm{mC}_{\mathrm{i}}\right)$ was added in $10 \mathrm{ml}$ of ATPase buffer containing $1.1 \mathrm{~g}$ of Ecc $\mathrm{A}_{1}$ and incubated for different time intervals at $37^{\circ} \mathrm{C} .1 \mu \mathrm{l}$ of the reaction buffer was spotted on TLC plate after every $10 \mathrm{~min}$. The TLC plate was developed in $0.5 \mathrm{M}$ formic acid and $0.5 \mathrm{M} \mathrm{LiCl}$ and dried at $37{ }^{\circ} \mathrm{C}$. The TLC plate was exposed to Fuji film BAS-MS 2025 imaging plate for $12 \mathrm{~h}$ and analyzed using Typhoon FLA-9500 (from GE Healthcare). The background obtained from reaction buffer (having no Ecc $_{1}$ and $\left(\gamma^{32 P}\right)$ ATP) was corrected in each ATP hydrolysis measurement.

Colorimetric assay was performed to analyze the EccA $A_{1}$ ATPase activity by using ATPase assay kit (Innova Biosciences, $U K$ ). The ATPase assay was performed in buffer containing (20mM HEPES pH 7.5, 150mM NaCl, 5\% Glycerol, 2mM $\beta$-mercaptoethanol, 1mM ATP and $1 \mathrm{mM}$ of $\mathrm{EccA}_{1}$ ). The reaction was carried out at $25{ }^{\circ} \mathrm{C}$ for $5 \mathrm{~min}$. The dye buffer containing (120mM malachite green, $0.06 \%$ polyvinylalcohol, $6 \mathrm{mM}$ ammonium heptamolybdate, $4.2 \%$ sodium citrate) was added in the reaction buffer. After incubating for $15 \mathrm{~min}, 10 \mu \mathrm{l}$ of each reaction mixture was transferred in 96 well plates and absorbance at $630 \mathrm{~nm}$ was measured. Absorbance from reaction buffer containing no $\mathrm{EccA}_{1}$ and without ATP was substracted from each experimental data. Release of inorganic phosphate was analyzed based on absorbance from 
phosphate standard curve. Each assay was performed three times and average activity was calculated. The values of kinetic parameters $K_{\mathrm{m}}$ and $V_{\max }$ were calculated using PRISM 6.0 software (Graph Pad Software Inc.).

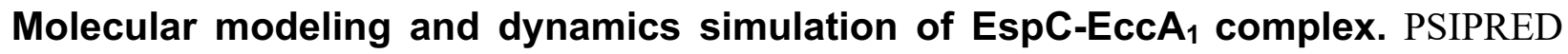

[32] program was used to predict the secondary structures of EspC and EccA . We obtained the EspC model by PHYRE2 server using WxG100 structure from $S$. agalactia (PDB-3GWK) as input. Full length EccA 1 model (1-573 residues) was obtained by MODELER program [33]. Following templates were used as input (i) crystal structure of TPR domain of Ecc $\mathrm{A}_{1}(1-273$ residues, PDB-4F3V) (ii) structural model of ATPase domain of EccA 1 (331-481 residues) obtained by PHYRE2 server using Rubisco ATPase structure (PDB-3SYL) as input template [34]. Best model was selected based on MODELER Z-DOPE score. The Ecc $A_{1}$ hexamer was built using COOT program [35] taking p97 hexamer (PDB-1E32) as input template [36]. Energy minimization was performed on EspC and Ecc $\mathrm{A}_{1}$ hexamer using GROMACS program[37]. PROCHECK program [38] was used to check the quality of EspC and EccA $\mathrm{A}_{1}$ models and ANOLEA program [39] to calculate the conformational energy.

ROSETTADOCK server [40] with protein-protein docking module was used to build the EspC-Ecc $A_{1}$ hexamer. The $\beta$ hairpin insertion motif (Ala81-Val96 residues) of TPR domain of Ecc $_{1}$ and YxxxD (Tyr87-Asp91 residues) motif of export arm of EspC were used as input constraints in protein-protein docking analysis. The docking server yielded the 10 best low energy clusters of EspC-EccA $\mathrm{A}_{1}$ complexes. Best model was selected based on binding energy, intermolecular interactions and buried surface area in the EspC $\sim \mathrm{EccA}_{1}$ complex. The PISA server was used to analyze the interactions, binding free energy and solvent accessibility in EspC $\sim \mathrm{EccA}_{1}$ complex. 
Energy minimization and dynamics simulation were performed on EspC $\sim$ Ecc $\mathrm{A}_{1}$ complex using GROMACS program [37]. The EspC-EccA 1 complex was immersed in cubic box extending $0.5 \mathrm{~nm}$ from protein surface and solvated with explicit SPC water molecules. The chloride and sodium ions were added to neutralize the whole system and simulated with periodic boundary conditions. The solvated complex system consists of 467,826 protein atoms surrounded by 1000,000 water molecules. Before running the dynamics simulation, whole system was energy minimized for 200 iterations of steepest descents and then equilibrated for $10 \mathrm{ps}$, during which protein atoms were restrained. All restraints were removed from the protein and temperature was gradually increased in 10 distinct steps of 5 ps simulation each. V- rescale (modified Berendsen thermostat) coupling was employed to maintain a constant $300 \mathrm{~K}$ temperature with a coupling constant of $0.2 \mathrm{ps}$. The coulomb cut off was 1.0. The time step employed was $2 \mathrm{fs}$ and coordinates are saved every $4 \mathrm{ps}$ for molecular dynamics trajectory analysis. The pressure was maintained by Parrinello-Rahman pressure coupling constant and coulomb cut off was applied during temperature coupling. The stereochemistry of simulated EspC $\sim \mathrm{EccA}_{1}$ complex was checked by PROCHECK program, secondary structure composition by DSSP program [41] and structure visualization by PyMOL [42] program.

\section{Binding analysis using wild type and mutant EspC and $E c c A_{1}$ proteins. Binding}

analysis between EspC and $\mathrm{EccA}_{1}$ was performed by surface plasmon resonance technique using BIAcore-3000 system (Biacore Pharmacia Biosensor AB, Uppsala Sweden). CM4 sensor chip was used for binding experiment and experiment was performed at $25^{\circ} \mathrm{C}$ in $\mathrm{HBS}-\mathrm{P}$ buffer containing (20mM HEPES buffer $\mathrm{pH} 7.5,150 \mathrm{mM} \mathrm{NaCl}$, 10mM Arginine, 10mM Glutamate, 0.02mM ATP, $0.02 \mathrm{mM} \mathrm{MgCl}_{2}$ ). The CM4 sensor chip contains carboxy-methylated dextran 
covalently attached to gold surface and protein was covalently coupled to sensor surface via amine, thiol, aldehyde or carboxyl groups.

The EccA $\mathrm{A}_{1}$ was immobilized on CM4 surface activated by EDC-NHS amine coupling chemistry. $170 \mu \mathrm{l}$ of $\mathrm{EccA}_{1}$ (conc. $\sim 60 \mu \mathrm{g} / \mathrm{ml}$ ) was diluted in sodium acetate buffer $\mathrm{pH} 4.1$ and injected over flow cells with $30 \mu \mathrm{l} / \mathrm{min}$. The $5100 \mathrm{RU}$ of $\mathrm{EccA}_{1}$ was immobilized on $\mathrm{CM} 4$ sensor chip surface and surface was blocked by ethanolamine. Four different concentrations of EspC $(0.5,1,2$, and $4 \mu \mathrm{M})$ were injected over immobilized Ecc $\mathrm{A}_{1}$ using HBS-P buffer pH 7.5 with 30 $\mu \mathrm{l} / \mathrm{min}$. The sensogram was allowed to run for another $5 \mathrm{~min}$. The biosensor surface was regenerated for another $10 \mathrm{~min}$ by using running buffer at $30 \mu \mathrm{l} / \mathrm{min}$. Association and dissociation kinetic constants were evaluated by BIAeveluation 3.0 software using simple 1:1 Langmuir model.

PCR based site directed mutagenesis was performed to obtain three deletion mutants of EspC, Surface plasmon resonance technique was used to obtain dissociation constant $\left(K_{D}\right)$ between $\mathrm{EccA}_{1}$ and three truncated mutants of EspC, (i) EspC- $\Delta 5$ (Met1-Asp99 residues) (ii) EspC- $\Delta 10$ (Met1-Trp93 residues) and (iii) EspC- $\Delta 20$ (Met1-Ala83 residues). To probe residues of EspC export arm involved in binding to $\beta$-hairpin insertion of TPR domain of Ecc $\mathrm{A}_{1}$, the EspC-W94A and EspC-Y87A mutants were generated. Binding analysis between five EspC mutants with Ecc $_{1}$ were performed by same protocol used for $\mathrm{EspC} \sim \mathrm{EccA} \mathrm{A}_{1}$ binding. Site directed mutants of $\operatorname{EccA}_{1}$ (D91A and Y89A in $\beta$-hairpin insertion of TPR domain) were generated and binding analysis was performed with EspC. The $K_{D}$ of two EccA 1 mutants were obtained and compared with $K_{D}$ value obtained for Ecc $\mathrm{A}_{1} \sim \mathrm{EspC}$ binding.

\section{Circular dichorism and thermal stability analysis on wild type and mutant EspC}

and EccA $_{1}$ proteins. $\mathrm{CD}$ measurements were recorded using Chirascan ${ }^{\mathrm{TM}} \mathrm{CD}$ 
spectropolarimeter (Applied Photophysics), which uses the water bath to maintain the constant temperature. The wild type and mutant EspC and $\mathrm{EccA}_{1}$ proteins were diluted to $0.1 \mathrm{mg} / \mathrm{ml}$ in $10 \mathrm{mM}$ potassium phosphate buffer $\mathrm{pH} 8.0$ and loaded in $0.1 \mathrm{~cm}$ quartz cuvette. The $10 \mathrm{mM}$ potassium phosphate buffer $\mathrm{pH} 8.0$ was used as blank for all $\mathrm{CD}$ measurments. The final CD spectrum was average of three sequential scan. All CD data were converted to mean residue ellipticity (deg.cm²/dmol).

The Dichroweb server [43] was used to estimate the secondary structures from CD spectra. The SOPMA [44], GOR [45] and PSIPRED programs were used to estimate theoretical secondary structures of EspC and $\mathrm{EccA}_{1}$ proteins. For thermal stability analysis of EspC and $\mathrm{EccA}_{1}, \mathrm{CD}$-spectra were recorded as a function of temperature. For $\mathrm{EccA}_{1}$, the CD spectra were recorded from $20^{\circ} \mathrm{C}-90^{\circ} \mathrm{C}$ in $10^{\circ} \mathrm{C}$ increment and $25^{\circ} \mathrm{C}-85^{\circ} \mathrm{C}$ in $10^{\circ} \mathrm{C}$ increment for EspC respectively.

\section{RESULTS}

EspC purification and characterization. The EspC protein (112 residues, $\mathrm{Mw} \sim 11.9 \mathrm{kD})$ contains a C-terminal export arm (with AA cradle, YSEADE and IDGLF motifs) involved in recognition to EccA $\mathrm{ATPase}_{1}$ (Figure 1A). The EspC was overexpressed in E. coli. BL21(DE3) cells and purified using Ni-NTA affinity and size exclusion chromatography (Figure 1B). Initially, the EspC was forming highly ordered oligomer and eluted in the void volume of Superdex 200(16/60) column. However, treatment with different additives improved the EspC solubility. Addition of $0.01 \%(\mathrm{w} / \mathrm{v})$ Tween-20 and $0.01 \%(\mathrm{w} / \mathrm{v})$ SDS in EspC buffer prevented the EspC oligomerization and protein eluted as hexamer on Superdex 200(16/60) column (Figure 1B). The mass spectrometric analysis on purified EspC (Figure S1) shows a single band and peak of EspC monomer $(\mathrm{Mw} \sim 11.8 \mathrm{kD})$. The EspC was purified to homogeneity and found biologically active based on A549 cytotoxicity assay and binding analysis with Ecc $\mathrm{A}_{1}$ ATPase. 
EspC is cytotoxic to human lung carcinoma A549 cells. Human macrophage and epithelial cells constitute the first line of defense after mycobacterial infection and induce the initial host defense response. The human lung carcinoma A549 is a long epithelial cell that protects the host from pathogen infection. To check whether EspC is cytotoxic to A549 cell, we have performed the EspC cytotoxicity experiment using A549 cells and examined the results using light microscopy and MTT assay.

As seen in MTT assay (Figure 2), viability of A549 cells decreased upon incubation with EspC protein. Four different concentrations of $\operatorname{EspC}(25,50,100$ and $200 \mu \mathrm{g} / \mathrm{ml})$ were incubated with A549 cells for different time points (2, 4, 6, 12 and 24 h). Viability of A549 cells decreased progressively with increasing concentration of EspC. There was significant decrease in A549 cells viability with EspC conc. of 100 and $200 \mu \mathrm{g} / \mathrm{ml}$, when compared with Bovine Serum Albumin in EspC buffer as a control (Figure 2). With $100 \mu \mathrm{g} / \mathrm{ml}$ of EspC at 2, 4, 6, 12 and $24 \mathrm{~h}$, $\%$ of cell viability $(53.9,41.8,37.5,17.6,4.73)$ was observed. With $200 \mu \mathrm{g} / \mathrm{ml}$ of EspC, $\%$ of cell viability $(4.4,1.46,1.36,1.23,0.75)$ was observed. Phospholipase-C was used as a positive control, which resulted significant decrease in A549 cells viability at all time points used in the study. Bovine Serum Albumin (Conc. $100 \mu \mathrm{g} / \mathrm{ml}$ dissolved in EspC buffer) did not show any significant decrease in cell viability (Figure 2). These results indicate that EspC is cytotoxic to the human lung carcinoma A549 cells.

EspC enters into A549 cells. To examine, whether EspC enters into A549 cells and indeed cytosolic, we stained the EspC $(100 \mu \mathrm{g} / \mathrm{ml})$ treated A549 cells with anti-His antibody and analyzed the cells using confocal microscopy (Figure 3). We examined the localization of EspC in A549 cells at 2, 4 and $6 \mathrm{~h}$ using confocal microscopy, as these time points resulted in 
equally significant decrease in cell viability as the later time-points. The confocal images show that EspC was localized in the cytosol of A549 cells after 2, 4 and $6 \mathrm{~h}$ of treatment. The A549 cells without EspC treatment did not stain with anti-His antibody. These results show that EspC enters into A549 cells and results in decreased cell viability.

To test the amount of EspC present in A549 cells, the EspC was incubated for 2, 4, and 6 $\mathrm{h}$ with A549 cells and presence of EspC in whole cell lysate was detected using anti-His antibody (Figure 4C). Specific bands corresponding to EspC were detected only in EspC treated A549 cell lysate and not in control experiment. The EspC band was detected at 2, 4 and $6 \mathrm{~h}$ of treatment of A549 cells with EspC.

EccA $_{1}$ shows the specific ATPase activity. The schematic view of EccA $A_{1}$ ATPase $(67 \mathrm{kD}$, 573 residues) is shown in Figure S2A. The The Ecc $\mathrm{A}_{1}$ protein was eluted as hexamer from Superdex 200(16/60) column and showed a single band on SDS-PAGE (Figure S2B). Initially, Ecc $_{1}$ was eluting in the void volume of Superdex 200(16/60) column, however addition of $10 \mathrm{mM}$ Arginine, $0.2 \mathrm{mM} \mathrm{MgCl}_{2}$ and $0.2 \mathrm{mM}$ ATP in protein buffer prevented the $\mathrm{EccA}_{1}$ oligomerization and protein eluted as hexamer. The AAA+ATPase proteins may form multiprotein complex inside the cell and higher ordered oligomers of Ecc $\mathrm{A}_{1}$ hexamer have been observed in earlier study also [46].

To examine the ATPase activity, EccA $\mathrm{A}_{1}$ was dialyzed in buffer containing no ATP. We performed sensitive radioactive assay on $\mathrm{EccA}_{1}$ using $\left[\gamma^{32 \mathrm{P}}\right] \mathrm{ATP}$ as a substrate and release of free phosphate was monitored (Figure S2A). The free phosphate was released linearly overtime and $K_{m}$ of $52.4 \pm 2.1 \mu \mathrm{m}$ and $V_{\max }$ of $1.51 \pm 0.7 \mu \mathrm{mol} / \mathrm{min}$ were obtained from Michaelis-Menten plot and nonlinear regression analysis using Prism 6.0 software (GraphPad Software) (Figure S2B). These data shows that EccA 1 is a weak ATPase, as also observed in earlier study [46]. 
Molecular modeling of EspC-EccA 1 complex. The sequence alignment of the export arm of EspC with other ESX-1 virulence proteins is shown in Figure 5A. The EspC may form homodimer, as observed for monocistronically expressed CFP10 and sagEsxA family proteins, which lack WxG motif (24). The model of EspC homodimer (Figure 5B) was obtained by PHYRE2 server (47), which used the sagEsxA structure (PDB-3GWK) as input template. As EspC eluted as hexamer from gel filtration column, we build the model of EspC hexamer by ROSETTADOCK server (40) using $\mathrm{C}_{\mathrm{n}}$ symmetry module (Figure $\mathrm{S} 4$ ). The lowest energy cluster was selected as the final model, which shows the export arms of the EspC on both sides of helical bundle and easily accessible for optimal interactions with Ecc $\mathrm{A}_{1}$.

The EccA 1 model was obtained using following constraints. The model of C-terminal ATPase domain (331-481 residues) of $\mathrm{EccA}_{1}$ was obtained using Rubisco ATPase structure (PDB: 3ZUH) as input. The structure of the N-terminal TPR domain (1-273 residues) was obtained from published structure of $M$. tuberculosis TPR domain (PDB: 4F3V) (31). The structure of full length EccA 1 (1-573 residues) was obtained by MODELER program [30, 36] using following structures, the N-terminal TPR domain, the C-terminal hexameric ATPase model and two loops connecting 273-331 residues and 481-573 residues respectively. The EccA1 hexamer was built using p97 hexamer structure (PDB-1E32) as input model (Figure 5C).

To build EspC-EccA 1 complex, ROSETTADOCK protein-protein docking server was used with following constraints (i) the $\beta$-hairpin motif (A81-V96 residues) of the TPR domain of Ecc $_{1}$ and YxxxD motif (Y87-D91 residues) of EspC homodimer as interacting partner in protein-protein docking calculation. Simulations with stoichiometric constraints resulted convergence to several low energy clusters of EspC-EccA $A_{1}$ complex. All low energy conformations have similar binding mode in EspC-EccA $\mathrm{A}_{1}$ complex and that provides greater 
confidence in proposed orientation of both molecules in EspC-EccA $\mathrm{A}_{1}$ complex. The lowest energy cluster was selected and dynamics simulation was performed on EspC-EccA 1 complex using GROMACS program [37] (Figure 6A-D).

PISA server [48] was used to analyze the interface between EspC and EccA 1 proteins. It

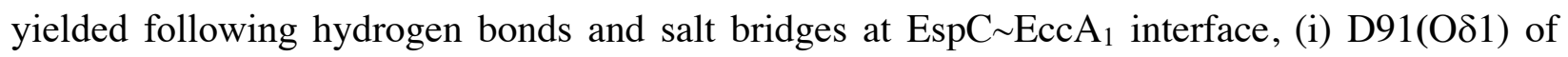
$\mathrm{EccA}_{1}$ with $\mathrm{Y} 87(\mathrm{~N})$ of EspC (ii) $\mathrm{Y} 89(\mathrm{OH})$ of $\mathrm{EccA}_{1}$ with W94(Nל) of EspC (iii) A112(O') of $\mathrm{EccA}_{1}$ with $\mathrm{A} 93(\mathrm{~N})$ of EspC (iv) $\mathrm{Y} 16(\mathrm{OH})$ of $\mathrm{EccA}_{1}$ with Ala93(O') of EspC (v) R206(Ne) of $\mathrm{EccA}_{1}$ with $\mathrm{Y} 87(\mathrm{OH})$ of EspC (vi) E238(Oe1) of $\mathrm{EccA}_{1}$ with $\mathrm{Y} 87(\mathrm{OH})$ of EspC and (viii) T234(O') of Ecc $\mathrm{A}_{1}$ with $\mathrm{R} 11\left(\mathrm{NH}_{1}\right)$ of EspC. These data indicate that EspC export arm interacts extensively with $\beta$-hairpin insertion of the TPR domain and N-terminal regions of the Ecc $\mathrm{A}_{1}$ ATPase.

EspC has a bipartite signal sequence that interacts with TPR domain of EccA ${ }_{1}$. The C-terminal export arm of EspC harbors the AA-cradle (A94-A95), YSEAD motif (Y87-D91) and IDGLF (I98-F102) motifs. The EspC export arm interacts with EccA $\mathrm{A}_{1}$ ATPase and required for EspC secretion by ESX-1 system [30]. To identify the residues and length of EspC export arm involved in $\mathrm{EccA}_{1}$ recognition, we prepared three truncated (EspC- $\Delta 5$, EspC- $\Delta 10$ and EspC$\Delta 20$ ) and two point mutants (W94A and Y89A) of EspC export arm, involved in binding to TPR domain of $\mathrm{EccA}_{1}$.

The surface plasmon resonance technique was used for binding analysis between EspC and $\mathrm{EccA}_{1}$, which showed the $K_{D}$ value of $\sim 0.14 \mu \mathrm{M} \pm 0.05 \mu \mathrm{M}$ (Figure 7A). From EspC-EccA complex model, we identified that EspC-Y87 residue forms hydrogen bond with D91 residue of $\beta$-hairpin insertion of TPR domain. The EspC-W94 residue forms hydrogen bond with Y89 residue of $\beta$-hairpin insertion of the TPR domain of $\mathrm{EccA}_{1}$. We performed the binding analysis 
of EspC-W94A mutant with $\mathrm{EccA}_{1}$ and obtained $K_{D}$ value of $9.1 \pm 0.8 \mu \mathrm{M}$ (Figure $7 \mathrm{~B}$ ) and $10.3 \pm 0.7 \mu \mathrm{M}$ for EspC-Y87A mutant (Figure $7 \mathrm{C}$ ). $\sim 65$ fold reduction in binding affinity for EspC-W94A mutant and $\sim 74$ fold reduction in binding affinity for EspC-Y87A mutant were observed, when compared with affinity between $\mathrm{EspC} \sim \mathrm{EccA}_{1}$. These results indicate that W94 and Y87 residues of EspC are critical in recognition to TPR domain of EccA.

To probe the length of EspC export arm involved in $\mathrm{EccA}_{1}$ recognition, we generated three truncated mutants (i) EspC- $\Delta 5$ (ii) EspC- $\Delta 10$ and (iii) EspC- $\Delta 20$. The EspC- $\Delta 5$ and EspC$\Delta 10$ mutants lack conserved IDGLF motif of the export arm and EspC- $\Delta 20$ mutant lacks full export arm (AA-cradle, YSEAD motif and IDGLF motif). Binding analysis of wild type EccA 1 with three truncated mutants of the EspC yielded following $K_{D}$ values, (i) EspC- $\Delta 5\left(K_{\mathrm{D}} \sim 6.7 \pm 0.2\right.$ $\mu \mathrm{M})$ (Figure 7D) (ii) EspC- $\Delta 10\left(K_{\mathrm{D}} \sim 8.1 \pm 0.1 \mu \mathrm{M}\right)$ (Figure 7E) and (iii) EspC- $\Delta 20$ (no binding) (Figure 7F). These results indicate that EspC- $\Delta 5$ mutant (lacking IDGLF motif) showed $\sim 40$ fold and EspC- $\triangle 10$ mutant (lacking WRKA-IDGLFT motif) shows $\sim 60$ fold decrease in binding affinity, when compared with wild type EspC affinity towards EccA $\mathrm{A}_{1}$ The EspC- $\Delta 20$ mutant (lacking full export arm consists of AA-cradle, YSEAD and IDGLF motifs) showed no binding to $\mathrm{EccA}_{1}$. Altogether, these results indicate that IDGLF motif of EspC export arm is critical for Ecc $\mathrm{A}_{1}$ binding and its deletion in EspC- $\Delta 5$ and EspC- $\Delta 10$ mutants leads to $\sim 40-60$ fold decrease in binding to EccA $\mathrm{A}_{1}$. Conserved AA-cradle, YSEAD and IDGLF motifs of EspC export arm are absolutely essential for Ecc $\mathrm{A}_{1}$ recognition and deletion of these motifs in EspC- $\Delta 20$ mutant leads to $\sim$ no binding to $\operatorname{EccA}_{1}$.

\section{$\beta$ hairpin insertion motif of TPR domain of $\operatorname{EccA}_{1}$ interacts specifically with}

export arm of EspC. Based on EspC-EccA 1 model, two point mutations (Y89A and D91A) in $\beta$-hairpin insertion motif of TPR domain were generated using site directed mutagenesis. D91 
residue of $\beta$-hairpin insertion forms hydrogen bond with Y87 residue of EspC export arm $\left({ }^{87} \mathrm{YxxxD}^{91}\right)$. The Y89 residue of $\beta$-hairpin insertion forms hydrogen bond with W94 residue of EspC export arm. Binding analysis of EspC with wild type \& two Ecc $\mathrm{A}_{1}$ mutants was performed using surface plasmon resonance technique. It shows that wild type EccA 1 binds to EspC with $K_{D}$ $\sim 0.14 \mu \mathrm{M}$ (Figure $8 \mathrm{~A}$ ). The EccA 1 -D91A mutant binds to EspC with $K_{D} \sim 3.2 \mu \mathrm{M}$ (Figure $8 \mathrm{~B}$ ) and $\mathrm{EccA}_{1}-\mathrm{Y} 89 \mathrm{~A}$ mutant binds to EspC with $K_{D} \sim 2.6 \mu \mathrm{M}$ (Figure $8 \mathrm{C}$ ). These data indicate that

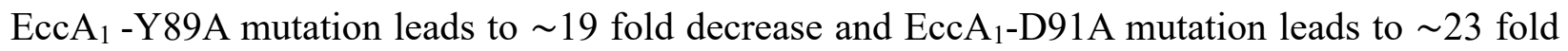
decrease in binding affinity to EspC, when compared with wild type Ecc $\mathrm{A}_{1}$. These results show that Y89 and D91 residues of $\beta$-hairpin insertion motif of TPR domain specifically recognize the EspC export arm and their mutations lead to significant decrease in EspC binding.

\section{The EspC and EccA 1 show quite similar secondary structures in wild and mutant}

proteins respectively. Far-UV CD spectra $(260-200 \mathrm{~nm})$ were obtained for native EspC, EspC-W94A, EspC-Y87A, EspC- $\Delta 5$, EspC- $\Delta 10$, and EspC- $\Delta 20$ mutants (Figure 9A-F). Dichroweb server was used to estimate the secondary structures and thermal stability of all proteins (Table 1) [43]. As seen from Table 1, the wild type EspC contains $\sim 80 \% \alpha$-helix and $~$ $20 \%$ random coil structures, which was quite similar to secondary structures in five EspC mutants. These results show that wild type and mutant EspC proteins retain quite similar structures. For thermal stability analysis, the CD spectra of EspC were recorded from $25^{0} \mathrm{C}$ $85^{\circ} \mathrm{C}$ in $10^{\circ} \mathrm{C}$ increment (Figure 9A). These data shows the thermal unfolding transition temperature $\left(\mathrm{T}_{\mathrm{m}}\right)$ of $32.2 \pm 1.0{ }^{0} \mathrm{C}$, which indicate that $\mathrm{EspC}$ is a quite thermostable protein.

Far-UV CD spectra (260-200 nm) were obtained for wild type EccA $1, E_{1} A_{1}-D 91 A_{\text {and }}$ Ecc $_{1}$-Y87A mutants (Fig 10A-D). Dichroweb server analysis on wild type and two EccA 1 mutants shows quite similar secondary structures $(\sim 60 \% \alpha$-helix, $\sim 7 \% \beta$-sheet and $\sim 33 \%$ 
random coil structures) (Table 1). The theoretical structure prediction analysis on Ecc $\mathrm{A}_{1}$ also shows the $\sim 60 \% \alpha$-helix, $\sim 4.3 \% \beta$-sheet, $\sim 35.2 \%$ random coil structures, which was quite similar to $\mathrm{CD}$ data. For thermal stability analysis, the $\mathrm{CD}$ spectrum for $\mathrm{Ecc}_{1}$ was collected from $20^{\circ} \mathrm{C}-90^{\circ} \mathrm{C}$ in $10^{\circ} \mathrm{C}$ increment (Figure $10 \mathrm{~B}$ ). It shows the thermal unfolding transition temperature $\left(\mathrm{T}_{\mathrm{m}}\right)$ of $49.3 \pm 0.1{ }^{0} \mathrm{C}$, which indicate that $\mathrm{EccA}_{1}$ is a quite thermostable protein.

\section{DISCUSSION}

In the current study, we have purified and analyzed the biological activities of EspC and Ecc $_{1}$ proteins. To understand the molecular mechanism involved in EspC $\sim$ Ecc $\mathrm{A}_{1}$ recognition, molecular modeling and docking techniques were used to obtain the EspC $\sim \operatorname{EccA}_{1}$ model. Based on modeled structure, critical residues involved in $\mathrm{EspC} \sim \mathrm{EccA}_{1}$ recognition were identified and EspC and $\mathrm{EccA}_{1}$ mutants were generated. To validate these interactions, binding analysis was performed using wild type and mutant EspC to $\mathrm{EccA}_{1}$ proteins respectively to dissect the molecular mechanism involved in $\mathrm{EspC}_{\sim} \mathrm{EccA}_{1}$ recognition. $\mathrm{CD}$ spectroscopy was used to identify the secondary structure and thermal stability of EspC and EccA $\mathrm{A}_{1}$ proteins as a result of all mutations.

We have expressed and purified the EspC protein in detergent solubilized form. The wild type and mutant EspC proteins eluted as hexamer from the size exclusion column. It is observed that EspC co-precipitates with EspA in cytosolic and membrane fractions of the mycobacterial cell [18]. In absence of EspA, the EspC may form homodimer as observed for monocistronically expressed CFP10 and sagEsxA family proteins, which lack WxG motif [24]. It appears that EspC hexamer may assemble as three copies of dimer in solution (Figure S4). The ESX-1 virulence proteins have been found to form multiprotein complex before their secretion by ESX-1 system.

The Mycobacteria uses the ESX-1 mediated membrane-puncturing mechanism for phagosomal permeabilization within infected host macrophage. By secreting EspC and other 
ESX-1 virulence proteins, mycobacteria may be able to escape phagosome and enter into the host cytosol. To examine whether EspC enters into the human lung carcinoma A549 cells and induce cytotoxicity, we incubated the EspC with A549 cells and examined the viability of the cells using MTT assay. The EspC cytotoxicity could be detected in A549 cells as early as $2 \mathrm{~h}$ of incubation and gradually increased. Contrary to our result, S. T. Cole group [18] has reported that they did not find any detectable cytotoxicity in RAW264.7 cells upon incubation with EspC for 2 h. The EspC enters into the A549 cells and accumulates in the cytosol, as observed in confocal microscopy and Western blotting analysis. Similar results were observed with Listeria monocytogenes bacterial proteins, which disrupt the vacuole membrane and help bacteria to enter in cytosol of host cell [40]. Significant cytotoxicity in A549 cells due to recombinant EspC was evident only at higher concentrations of EspC. This could be due to limited permeability of the recombinant EspC in A549 cells and hence lesser effective concentration inside the target cells under in vitro conditions. During natural infection of the target macrophages with Mycobacterium, the protein might be directly injected inside the cell and hence higher effective concentration.

The EccA 1 belongs to $\mathrm{CbxX/CfxQ}$ family of ATPases, a classical AAA+ ATPase protein family. The EccA $\mathrm{A}_{1}$ forms hexamer through C-terminal ATPase domain and contains a unique Nterminal TPR domain. We have performed the ATPase assay using full length Ecc $\mathrm{A}_{1}$, which shows weaker ATPase activity compared to other $\mathrm{AAA}^{+}$ATPases. In earlier study [46], fulllength EccA $\mathrm{A}_{1}$ had shown weaker ATPase activity, when compared with ATPase activity of Cterminal domain alone. Other $\mathrm{AAA}^{+}$ATPase enzymes also have shown weaker ATPase activity like E. coli. ClpB [47]. It is observed that loading of EspC on N-terminal TPR domain of EccA 1 enhances the ATPase activity [46]. The ClpB ATPase activity is also enhanced in presence of casein [47], as observed in case of $\mathrm{EccA}_{1}$ protein. 
The TPR domain uses its concave groove for protein-protein interaction and usually found in multi-protein complexes [48-51]. The Ecc $\mathrm{A}_{1}$ uses the concave groove of TPR domain for EspC binding, however a $\beta$-hairpin insertion in observed in the concave groove, which may form extended $\beta$-strand complementation with export arm of the EspC. The EspC may also interact on the side of concave groove of TPR domain as observed in P67-TPR/Rac complex structure [52]. To understand this mechanism, we have modeled the EspC $\sim$ Ecc $\mathrm{A}_{1}$ complex and found that $\beta$-hairpin insertion of TPR domain interacts extensively with EspC export arm. Based on these interactions, we designed $\mathrm{EspC}$ and $\mathrm{EccA}_{1}$ mutants and performed binding analysis using wild type and mutant proteins. Mutations in EspC export arm/ or in $\beta$ hairpin insertion of TPR domain leads to significant reduction in binding affinity between EspC and Ecc $\mathrm{A}_{1}$ in comparison to wild type EspC $\sim \mathrm{EccA}_{1}$ affinity. To examine, whether wild type and mutant EspC and $E_{1} A_{1}$ proteins maintain the similar structures, we performed the CD spectroscopy and thermal stability analysis on wild type and mutant proteins. No significant changes in secondary structures were observed in mutant proteins, when compared with wild type EspC and EccA 1 proteins.

These results have allowed us to rationalize the binding mechanism and specificity determinants at EspC $\sim \mathrm{EccA}_{1}$ interface. Biochemical results obtained from binding analysis of wild type and mutant proteins are in good agreement with interactions observed at EspC $\sim \mathrm{EccA}_{1}$ interface. Truncation/mutation in EspC export arm or point mutations in $\beta$-hairpin insertion of TPR domain of $\mathrm{EccA}_{1}$ caused significant decrease/or abolished the EspC EccA $\mathrm{A}_{1}$ binding. Interactions observed at EspC $\sim \mathrm{EccA}_{1}$ interface are quite similar to the interactions observed in Rac/p67-TPR domain complex. In Rac/p67-TPR domain complex, Rac binds p67-TPR concave groove in extended chain conformation and binding occurs exclusively with $\beta$-hairpin insertion. 
TPR domains are quite versatile in target recognition and follow the general rule for scaffolding the multiprotein complex assembly as observed in EspC $\sim \mathrm{EccA}_{1}$ complex.

\section{CONCLUSION}

In summary, we have purified and functionally characterized the EspC protein. The EspC enters and accumulated in the cytosol of human lung carcinoma A549 cells and caused the cell death. The purified EccA $\mathrm{A}_{1}$ exits as a hexamer and interacts extensively with EspC export arm though its $\beta$-hairpin insertion of TPR domain. It is the first detailed characterization on biological activities and mechanism of recognition between of EspC and $E_{c c} \mathrm{~A}_{1}$ proteins. Current knowledge will contribute significantly in the development of novel inhibitors, which will prevent the virulence proteins secretion by mycobacterial ESX-1 secretion system.

\section{AUTHOR INFORMATION}

Corresponding author

Email: ajaysaxena@mail.jnu.ac.in. Phone-011-26704155,

\section{Acknowledgements}

Current project is supported by research grant from the Department of Science and Technology, India (No.-SR/SO/BB-0104/2012).Vipin K. Kashyap is supported by Senior Research Fellowship from UGC, India. Ruby Sharma is supported by Senior Research Fellowship from CSIR. Research grants from UGC-Networking and DST-PURSE from Jawaharlal Nehru University (JNU), New Delhi are gratefully acknowledged. The authors thank the staff members of Advanced Instrumentation Research Facility (AIRF), Jawaharlal Nehru University for their help in conducting the $\mathrm{CD}$ experiments. 


\section{Author contributions}

Vipin K. Kashyap was involved in purification of the EspC and EccA $\mathrm{A}_{1}$ proteins, performed the EspC cell lysis and EccA $A_{1}$ ATPase assay, and performed binding analysis with native and mutant EspC and EccA 1 proteins. Ruby Sharma prepared all EspC point mutants, purified all proteins and performed binding analysis with native and mutant EspC and $\mathrm{EccA}_{1}$ proteins. Ruby Sharma was involved in A549 cytotoxicity experiment and collected CD data on all EspC and EccA mutant proteins. During manuscript revision, Manoj and Abhishek were involved in A549 cellular cytotoxicity experiments. Ajay K. Saxena analyzed the entire data of all experiments, performed, CD data analysis, modeling and dynamics simulation of EspC-Ecc $\mathrm{A}_{1}$ complex, prepared all figures and wrote the entire manuscript.

\section{Conflict of interest}

The authors declare they have no conflict of interest.

\section{ABBREVIATIONS}

ATP, Adenosine Triphosphate; EspC, ESX-1 secreted protein C; EspB, ESX-1 secreted protein B; EccA1, ESX-1 conserved AAA+ATPase; CFP10, Culture Filtrate protein-10; ESAT6, Early Secretory Antigen Target-6; CD, Circular Dichroism; TPR, Tertratricopeptide repeat; OD, Optical Density; Ni-NTA, Nickel-Nitriloacetic Acid; SDS PAGE, Sodium Dodecyl Sulfate Polyacrylamide Gel Electrophoresis; SPR, Surface Plasmon Resonance; PBS buffer, Phosphate buffered saline; PBST buffer, Phosphate buffered saline with Tween-20.

\section{ACCESSION IDS}


bioRxiv preprint doi: https://doi.org/10.1101/2021.09.24.461649; this version posted September 24, 2021. The copyright holder for this preprint (which was not certified by peer review) is the author/funder. All rights reserved. No reuse allowed without permission.

EspC protein UniProt ID: P9WJD7

EccA $_{1}$ protein UniProt ID: P9WPH9 


\section{REFERENCES}

1. Watson, R.O., Manzanillo, P.S., and Cox, J.S. (2012) Extracellular M. tuberculosis DNA Targets Bacteria for Autophagy by Activating the Host DNA-Sensing Pathway. Cell 150, 803-815.

2. van der Wel, N., Hava, D., Houben, D., Fluitsma, D., van Zon., Pierson, M., et al. (2007) M. tuberculosis and M. leprae translocate from the phagolysosome to the cytosol in myeloid cells. Cell 129, 1287-1298.

3. Simeone, R., Bobard, A., Lippmann, J., Bitter, W., Majlessi, L., \& Brosch R, et al. (2012) Phagosomal Rupture by Mycobacterium tuberculosis Results in Toxicity and Host Cell Death. PLoS Pathog 8, e1002507, 1-13.

4. Simeone, R., Sayes, F., Song, O., Gröschel, M.I., Brodin, P., Brosch, R., and Majlessi, L.(2015) Cytosolic access of Mycobacterium tuberculosis: critical impact of phagosomal acidification control and demonstration of occurrence in vivo. PLoS Pathog 8, 1004650, 124.

5. Russell, D.G. (2016) The ins and outs of the Mycobacterium tuberculosiscontaining vacuole. Cell Micro 18, 1065-1069.

6. Smith, J., Manoranjan, J., Pan, M., Bohsali, A., Xu, J., Liu, J., McDonald, K.L., Sfzyk, A., LeBlanc, N.L., and Gao, L.Y. (2008) Evidence for Pore Formation in Host Cell Membranes by ESX-1Secreted ESAT-6 and Its Role in Mycobacterium marinum Escape from the Vacuole. Infect Immun 76, 5478-5487.

7. Hsu, T., Hingley-Wilson, S.M., Chen, B., Chen, M., Dai, A.Z., Morin, P.M., Marks, C.B., Padiyar, J., Goulding, C., and Gingery, M., et al. (2003) The primary mechanism of attenuation of Bacillus Calmette-Guerin is a loss of secreted lytic function required for invasion of lung interstitial tissue. Proc Natl Acad Sci USA 100, 12420.

8. Gao, L.Y., Pak, M., Kish, R., Kajihara, K., and Brown, E.J. (2006) A mycobacterial operon essential for virulence in vivo and invasion and intracellular persistence in macrophages. Infect Immun 74, 1757-1767.

9. deJonge, M.I., Pehau-Arnaudet, G., Fretz, M.M., Romain, F., Bottai, D. and Brodin, P. et al. (2007) ESAT-6 from Mycobacterium tuberculosis dissociates from its putative chaperone CFP-10 under acidic conditions and exhibits membrane-lysing activity. J Bacteriol 189, 6028-6034.

10. Pathak, S.K., Basu, S., Basu, K.K., Banerjee, A., Pathak, S., and Bhattacharya, A., et al. (2007) Direct extracellular interaction between the early secreted antigen ESAT-6 of Mycobacterium tuberculosis and TLR2 inhibits TLR signaling in macrophages. Nat Immunol 8, 610-618.

11. Pallen, M.J. (2002) The ESAT-6/WXG100 superfamily and a new Gram-positive secretion system? Trends Microbiol 10, 209-212. 
12. Guinn, K.M., Hickey, M.J., Mathur, S.K., Zakel, K.L., Grotzke, J.E., Lewinsohn, D.M., Smith, S., and Sherman, D.R. (2004) Individual RD1-region genes are required for export of ESAT-6/CFP-10 and for virulence of Mycobacterium tuberculosis. Mol Microbiol 51, 5135951370.

13. Pym, A.S., Brodin, P., Majlessi, L., Brosch, R., Demangel, C., Williams, A., Griffiths, K.E., Marchal, G., Leclerc, C., and Cole, S.T. (2003) Recombinant BCG exporting ESAT-6 confers enhanced protection against tuberculosis. Nat Med 9, 9533-9539.

14. Millington, K.A., Fortune, S.M., Low, J., Garces, A., Hingley-Wilson, S.M., and Wickremasinghe, M. (2011) Rv3615c is a highly immunodominant RD1 (Region of Difference 1)-dependent secreted antigen specific for Mycobacterium tuberculosis infection. Proc Natl Acad Sci USA 108, 5730-5735.

15. Boesen, H., Jensen, B.N., Wilcke. T., and Andersen, P. (1995) Human T-cell responses to secreted antigen fractions of Mycobacterium tuberculosis. Infect Immun 63, 1491-1497.

16. Fisher, M.A., Plikaytis, B.B., and Shinnick, T.M. (2002) Microarray analysis of the Mycobacterium tuberculosis transcriptional response to the acidic conditions found in phagosomes. J Bacteriol 184, 4025-4032.

17. Rodriguez, G.M., Voskuil, M.I., Gold, B., Schoolnik, G.K., and Smith, I. (2002) IdeR, An essential gene in Mycobacterium tuberculosis: role of IdeR in iron-dependent gene expression, iron metabolism, and oxidative stress response. Infect Immun 70, 3371-3381.

18. Lou, Y., Rynibker, J., Sala, C., and Cole, S.T. (2016) EspC forms a filamentous structure in the cell envelope of Mycobacterium tuberculosis and impacts ESX-1 secretion. Mol Microbiol 103, 26-38.

19. Champion, P.A., Stanley, S.A., Champion, M.M., Brown, E.J., and Cox, J.S. (2006) CTerminal Signal Sequence Promotes Virulence Factor Secretion in Mycobacterium tuberculosis. Science 313, 1632-1636.

20. Daleke, M.H., Ummels, R., Bawono, P., Heringa, J., Vandenbroucke-Grauls, C.M., and Luirink, J. (2012) General secretion signal for the mycobacterial type VII secretion pathway. Proc Natl Acad Sci U S A 109, 11342-11347.

21. Arbing, M.A., Chan, S., Harris, L., Kuo, E., Zhou, T.T., and Ahn, C.J. (2013) Heterologous expression of mycobacterial Esx complexes in Escherichia coli for structural studies is facilitated by the use of maltose binding protein fusions. PLoS One 8, e817531-15.

22. Arbing, M.A., Kaufmann, M., Phan, T., Chan, S., Cascio, D., and Eisenberg, D. (2010) The crystal structure of the Mycobacterium tuberculosis Rv3019c-Rv3020c ESX complex reveals a domain-swapped heterotetramer. Protein Sci 19, 1692-1703.

23. Ilghari, D., Lightbody, K.L., Veverka, V., Waters, L.C., Muskett, F.W., and Renshaw, P.S. et al., (2011) Solution structure of the Mycobacterium tuberculosis EsxG·EsxH complex: functional implications and comparisons with other $M$. tuberculosisEsx family complexes. $J$ Biol Chem 286, 29993-30002. 
24. Poulsen, C., Panjikar, S., Holton, S.J., Wilmanns, M., and Song, Y.H. (2014) WXG100 Protein Superfamily Consists of Three Subfamilies and Exhibits an $\alpha$-Helical C-Terminal Conserved Residue Pattern. PLoS One 9, e89313 (1-12).

25. Renshaw, P.S., Lightbody, K.L., Veverka,V., Muskett, F.W., Kelly, G., and Frenkiel, T., et al., (2005) Structure and function of the complex formed by the tuberculosis virulence factors CFP-10 and ESAT-6. EMBO J 24, 2491-2498.

26. Solomonson, M., Setiaputra, D., Makepeace, K.A., Lameignere, E., Petrotchenko, E.V., and Conrady, D.G. (2015) Structure of EspB from the ESX-1 type VII secretion system and insights into its export mechanism. Structure 23, 571-583.

27. Sysoeva, T.A., Zepeda-Rivera, M.A., Huppert, L.A., and Burton, B.M. (2014) Dimer recognition and secretion by the ESX secretion system in Bacillus subtilis. Proc Natl Acad Sci U S A 111, 7653-7658.

28. Rosenberg, O.S., Dovala, D., Li, X., Connolly, L., Bendebury, A., Moore, J.F., Holton, J., Cheng, Y., Stroud, R.M., and Cox, J.S. (2015) Substrates Control Multimerization and Activation of the Multi-domain ATPase Motor of Type VII Secretion. Cell 161, 501-512.

29. Joshi SA, Ball DA, Sun MG, Carlsson F, Watkins BY \& Aggarwal N et al., (2012) EccA , a component of the Mycobacterium marinum ESX-1 protein virulence factor secretion pathway, regulates mycolic acid lipid synthesis. Chem Biol 19, 372-380.

30. Champion PA, Champion MM, Manzanillo P \& Cox JS (2009) ESX-1 secreted virulence factors are recognized by multiple cytosolic AAA ATPases in pathogenic mycobacteria. Mol Microbiol 73, 950-962.

31. Wagner JM, Evans TJ \& Korotkov KV (2014) Crystal structure of the N-terminal domain of EccA5 ATPase from the ESX-1 secretion system of Mycobacterium tuberculosis. Proteins 82, 159-163.

32. McGuffin, L.J., Bryson, K., and Jones, D.T. (2000) The PSIPRED protein structure prediction server. Bioinformatics 16, 404-405.

33. Webb, B., and Sali, A. (2014) Comparative protein structure modeling using MODELLER. Curr Protoc Bioinformatics 47, 5.6.1-5.6.32.

34. 31. Mueller-Cajar, O., Stotz, M., Wendler, P., Hartl, F.U., Bracher, A., and Hayer-Hartl, M. (2011) Structure and function of the AAA+ protein CbbX, a red-type Rubiscoactivase. Nature 479, 194-199.

35. Emsley, P., and Cowtan, K. (2004) COOT: Model-building tools for molecular graphics. Acta Crystallogr D Biol Crystallogr 60, 2126-2132.

36. Zhang, X., Shaw, A., Bates, P.A., Newman, R.H., Gowen, B., Orlova, E., Gorman, M.A., Kondo, H., Dokurno, P., Lally, J., Leonard, G., Meyer, H., Van Heel, M., and Freemont, P.S. (2000) Structure of the AAA+ ATPase P97, Mol Cell 6, 1473 -1484. 
37. Hess, B., Kutzner, C., van der Spoel, D., and Lindahl, E. (2008) GROMACS 4: Algorithms for Highly Efficient, Load-Balanced, and Scalable Molecular Simulation. J Chem Theory Comput 4, 435-447.

38. Laskowski, R.A., MacArthur, M.W., Moss, D.S., and Thornton, J.M. (1993) PROCHECK -a program to check the stereochemical quality of protein structures. J App Cryst 26, 283-291.

39. Melo, F., Devos, D., Depiereux, E., and Feytmans, E. (1997) ANOLEA: a www server to assess protein structures. Proc Int Conf Intell Syst Mol Biol 5,187-190.

40. Lyskov, S., and Gray, J.J. (2008) The RosettaDock server for local protein-protein docking. Nucleic Acids Res 36, 233-238.

41. Kabsch, W., and Sander, C. (1983) Dictionary of protein secondary structure: Pattern recognition of hydrogen-bonded and geometrical features. Biopolymers 22, 2577-2637.

42. DeLano, W.L. (2002) The PyMOL molecular graphics system. http://www.pymol.org.

43. Whitmore, L., and Wallace, B.A. (2008) Protein secondary structure analyses from circular dichroism spectroscopy: methods and reference databases. Biopolymers 89, 392-400.

44. Geourjon, C., and Deleage, G. (1995) SOPMA: significant improvements in protein secondary structure prediction by consensus prediction from multiple alignments. Comput Appl Biosci 11, 681-684.

45. Sen, T.Z., Jernigan, R.L., Garnier, J., and Kloczkowski, A. (2005) GOR-V server for protein secondary structure prediction. Bioinformatics 21, 2787-2788.

46. Luthra, A., Mahmood, A., Arora, A., and Ramachandran, R. (2008) Characterization of Rv3868, an essential hypothetical protein of the ESX-1 secretion system in Mycobacterium tuberculosis. J Biol Chem 283, 36532-36541.

47. Kelley, L.A., Mezulis, S., Yates, C.M., Wass, M.N., and Sternberg, M.J. (2015) The Phyre2 web portal for protein modeling, prediction and analysis. Nat Prot 10, 845-858.

48. Krissinel, E., and Henrick, K. (2007) Inference of macromolecular assemblies from crystalline state. J Mol Biol 372, 774-797.

49. Barnett, M.E., Zolkiewska, A., and Zolkiewski, M. (2000) Structure and activity of ClpB from Escherichia coli. Role of the amino and carboxyl terminal domains. $J$ Biol Chem $275,37565-37571$.

50. D'Andrea, L.D., and Regan, L. (2003) TPR proteins: the versatile helix. Trends Biochem Sci 28, 655-662.

51. Lamb, J.R., Tugendreich, S., and Hieter, P. (1995) Tetratricopeptide repeat interactions: to TPR or not to TPR? Trends Biochem Sci 20, 257-259. 
52. Blatch, G.L., and Lassle, M. (1999) Thetetratricopeptide repeat: a structural motif mediating protein-protein interactions. Bio Essays 21, 932-939.

53. Lapouge, K., Smith, S.J., Walker, P.A., Gamblin, S.J., Smerdon, S.J. and Rittinger, K. (2000) Structure of the TPR domain of p67phox in complex with Rac GTP. Mol Cell 6, 899-907.

54. Rasband, W.S. (1997-2014) Image J. National Institute of Health, Bethesda, Maryland, USA. 


\section{Figures legends}

Figure 1. A, The schematic view of EspC and its expression construct. The EspC export arm consists of AA cradle, YSEADE motif and IDGLF motif. B, Size exclusion chromatography and SDS-PAGE analysis of purified EspC. EspC eluted as hexamer from Superdex200 (16/60) column and shows a single band on SDS-PAGE.

Figure 2. The purified EspC is cytotoxic to A549 cells. MTT assay was performed to evaluate the cytotoxic potential of EspC in A549 cells. A549 cells were treated with the EspC (Conc. 20, 50,100 and $200 \mu \mathrm{g} / \mathrm{ml}$ ) for 2, 4, 6, 12 and $24 \mathrm{~h}$. The BSA (Bovine serum albumin) dissolved in EspC-buffer containing detergents was used as negative control. The phospholipase-C (PLC) in EspC buffer was used as positive control for cytotoxic lysis experiment. After incubation, the A549 cells were harvested and treated with MTT (conc. $\sim 5 \mathrm{mg} / \mathrm{ml}$ ). The Live cells and dead cells using MTT assay were counted at different conditions. The graph shows total number of live cells (Y-axis) plotted for different time durations (X-axis) under different conditions. Ns-non significant, $* * * \mathrm{P}<0.001, * * * * \mathrm{P}<0.0001$

Figure 3. The EspC protein is localized intracellular in the A549 cells. Representative images of confocal microscopy showing the EspC accumulation at 0,2, 4 and $6 \mathrm{~h}$ post treatment with EspC protein. A549 cells were seeded on coverslip and after 24 h cells were treated with EspC-buffer (mock) and with Esp Cprotein(conc. $100 \mu \mathrm{g} / \mathrm{ml}$ )for 2, 4, $6 \mathrm{~h}$. The presence of EspC protein (green) was tested with anti-His antibody, as EspCwas tagged with 6xHis. DAPI and Merge (His-EspC + DAPI) images are shown. White scale bar is $10 \mu \mathrm{m}$. 
Figure 4. A, The EspC accumulates inside the A549 cells gradually with time. Representative images show the EspC protein $(100 \mu \mathrm{g} / \mathrm{ml}$, green) treated with A549 cells for different time points, 2, 4 and $6 \mathrm{~h}$. B, Quantitative estimation of fluorescence intensity at each time was performed using Image $\mathrm{J}$ software [54]. The relative intensity (Y-axis) was plotted for different time points (X-axis). The graph represents the data from two independent biological experiments performed in duplicates. The error bars represent standard deviation in two experiments. White scale bar is $10 \mu \mathrm{m}$. C, The EspC enters and localize inside the A549 cells. The EspC protein (conc. $\sim 100 \mu \mathrm{g} / \mathrm{ml}$ ) was incubated for different time points $(2,4$, and $6 \mathrm{~h}$ ) with A549 cells. The treated cells were tested for EspC presence inside the A549 cells by Western blot analysis. A blot probed with anti His-antibody (for detection of EspC protein) showed the accumulation of EspC protein after 2, 4 and $6 \mathrm{~h}(+)$. The negative control (-) (no EspC incubation) did not show presence of EspC. A parallel blot probed with anti $\beta$-actin antibody is shown as a loading control. Numbers between His-tagged EspC and $\beta$-actin denote the relative intensity of EspC band.

Figure 5. A, Sequence alignment of export arm of EspC with other ESX-1 virulence proteins. The conserved AA-cradle, YxxxD motif and ALD motif of the EspC protein are shown in red bracket. The Web-LOGO diagram is shown above the sequence alignment. B, The EspC dimer is modeled using SagEsxA structure as input template. The red color indicates the YxxxD motif of the export arm of EspC, involved in binding to $\mathrm{EccA}_{1}$. C, The EccA $\mathrm{A}_{1}$ hexamer model is obtained using the Modeler program. The yellow color indicates the N-terminal TPR domain, and green color shows the C-terminal ATPase domain of the EccA $\mathrm{A}_{1}$

Figure 6. A, Homology modeling, protein-protein docking and dynamics simulation were used to obtain the EspC-EccA 1 complex model. The EspC homodimer (cyan), TPR domain (yellow) 
and ATPase domain are shown in green color. $\beta$-hairpin insertions of TPR domain of EccA1 and export arm of EspC are shown in red color. B, The EspC-Ecc $\mathrm{A}_{1}$ complex view after $90^{0}$ of rotation. $\mathbf{C}$, closer view of interactions between EspC exports arm and $\beta$-hairpin insertion of TPR domain of $\mathrm{EccA}_{1}$. D, Root mean square deviation of $\mathrm{C} \alpha$ atoms during dynamics simulation with respect to the starting structure.

Figure 7. The binding analysis of $\mathrm{EccA}_{1}$ was performed with five EspC mutants using surface plasmon resonance technique. A, Binding analysis of Ecc $\mathrm{A}_{1}$ with EspC. B, Binding analysis of

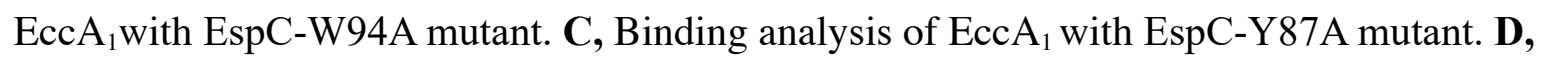
Binding analysis of $\operatorname{EccA}_{1}$ with EspC- $\Delta 5$ mutant. E, Binding analysis of Ecc $\mathrm{A}_{1}$ with EspC- $\Delta 10$ mutant. F, Binding analysis of $\mathrm{EccA}_{1}$ with EspC- $\Delta 20$ mutant. The concentrations of EspC mutants used in Ecc $\mathrm{A}_{1}$ binding and obtained $K_{D}$ values are shown in the each figure.

Figure 8. A, Binding analysis of EspC with $\mathrm{EccA}_{1}$ mutants using surface plasmon resonance technique. A, Binding analysis of EspC with $\mathrm{EccA}_{1} . \mathbf{B}$, Binding analysis of EspC with Ecc $\mathrm{A}_{1-}$ D91A mutant. C, Binding analysis of EspC and $\mathrm{EccA}_{1}$-Y89A mutant. The concentrations of the Ecc $\mathrm{A}_{1}$ mutants used in EspC binding and obtained $K_{D}$ values are shown in each figure.

Figure 9. A, Circular dichorism and thermal stability profile of EspC. B-C, Circular dichorism spectra of EspC-W94A and EspC-Y87A mutants. D-F, Circular dichorism spectra of EspC- $\Delta 5$, EspC- $\Delta 10$ and EspC- $\Delta 20$ mutants. Secondary structures of wild type and mutants EspC were determined using Dichroweb server and yielded quite similar values, as shown in each figure. Thermal stability analysis on EspC shows the $\mathrm{T}_{\mathrm{m}} \sim 32.1^{\circ} \mathrm{C}$ 
Figure 10. A-B, Circular dichorism and thermal stability spectra of the EccA $A_{1}$ C-D, Circular dichorism spectra of EccA 1 -Y89A and EccA 1 -D91A mutants. Spectra were recorded at room temperature and normalized to mean residue ellipticity. 


\section{Supplementary figures legends}

Figure S1. The mass spectrometric analysis of purified EspC protein obtained from gel filtration column. The major peak corresponds to molecular weight of the EspC monomer $\sim 11.9 \mathrm{kD}$.

Figure S2. A, Schematic diagram of various domains of $\operatorname{EccA}_{1}$ ATPase and its expression construct used for protein expression, TPR-tetratricopeptide repeat, ATPase-ATP binding domain. B, Size exclusion chromatography and SDS-PAGE analysis on purified Ecc $A_{1}$. The Ecc $\mathrm{A}_{1}$ eluted as hexamer from Superdex 200(16/60) column.

Figure S3. A, The EccA ${ }_{1}$ was incubated with $\left[\gamma^{32} \mathrm{P}\right]$ ATP and ATPase activity was determined at regular time intervals. The amount of hydrolyzed ATP is shown as a percentage of original $\left[\gamma^{32} \mathrm{P}\right]$ ATP. Each point is the average of three independent experiments. The inset shows the plot of ATP hydrolysis $\sim$ protein concentration and autoradiography profile was obtained from thin layer chromatography. B, Michaelis-Menten plot of ATP hydrolysis of the EccA 1 .

Figure S4. Molecular model of EspC hexamer was obtained by $\mathrm{C}_{\mathrm{n}}$ symmetry module of ROSETTADOCK protein-protein docking server using EspC dimer as input model. The lowest energy cluster was chosen as best model and export arms of EspC hexamer are shown as the circle. 
Table 1: Circular dichorism analysis of wild and mutant EspC and $\mathrm{CccA}_{1}$ proteins

\begin{tabular}{|l|l|l|l|}
\hline Protein & $\alpha$-helix & $\beta$-sheet & Random coil \\
\hline Wild EspC & $80 \%$ & - & $20 \%$ \\
\hline EspC-Y89A mutant & $80 \%$ & - & $20 \%$ \\
\hline EspC-W94A mutant & $80 \%$ & - & $20 \%$ \\
\hline EspC- $\Delta 5$ mutant & $73 \%$ & $2 \%$ & $25 \%$ \\
\hline EspC- $\Delta 10$ mutant & $76 \%$ & $2 \%$ & $22 \%$ \\
\hline EspC- $\Delta 20$ mutant & $83 \%$ & - & $17 \%$ \\
\hline Wild EccA 1 & $60 \%$ & $7 \%$ & $33 \%$ \\
\hline Ecc $A_{1}-Y 87$ A mutant & $69 \%$ & $10 \%$ & $21 \%$ \\
\hline EccA $A_{1}-\mathrm{D} 91 \mathrm{~A}$ mutant & $63 \%$ & $10 \%$ & $27 \%$ \\
\hline
\end{tabular}


$\begin{array}{ll}\text { A } & \text { Fig. } 1\end{array}$

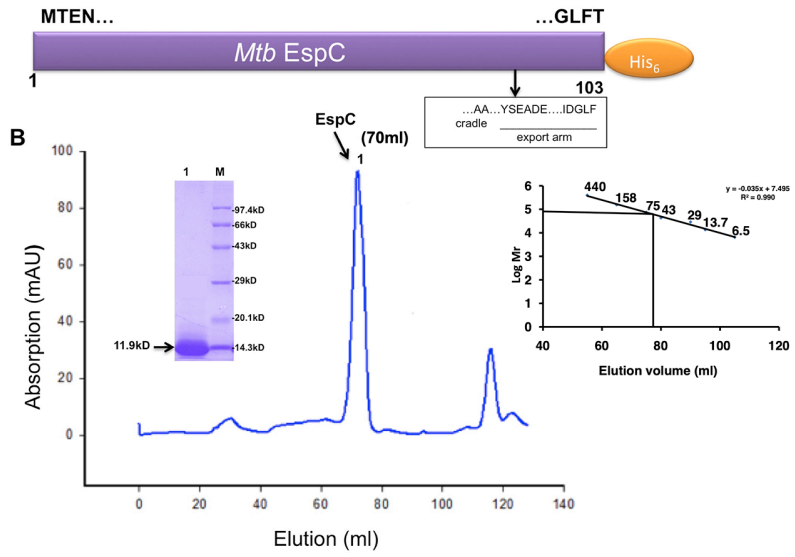


Fig. 2

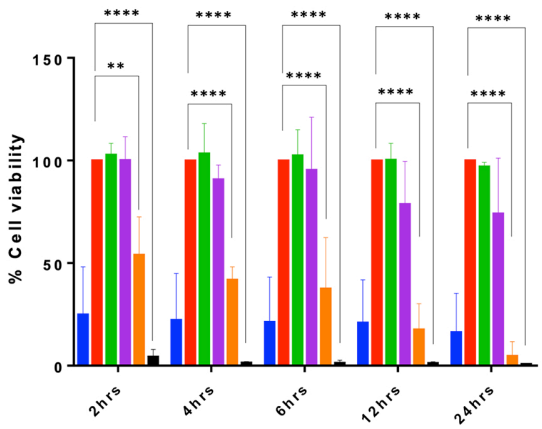

- PLC(50 ug/m I)

- BSA(100 ug/m I)

Espc(25 ug/mI)

Espc(50 ug/m I)

Espc(100 ug/m I)

Espc(200 ug/m I)

Tim e 
Fig. 3

Mock

O h

$2 \mathrm{~h}$

$4 \mathrm{~h}$

$6 \mathrm{~h}$

His-EspC + FITC
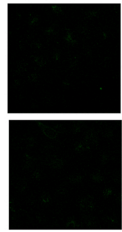

EspC (100ug/ml)
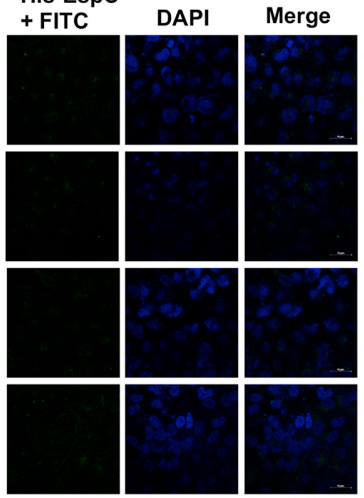

His-EspC

+ FITC

DAPI
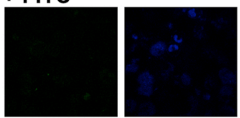

Merge
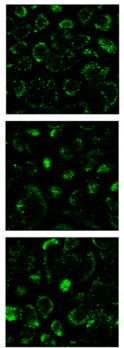
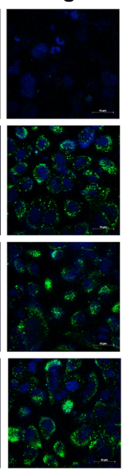
Fig. 4 EspC $(100 \mu \mathrm{g} / \mathrm{ml})$
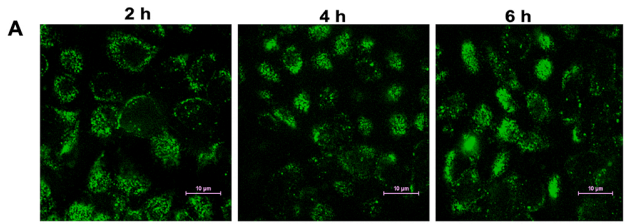

B

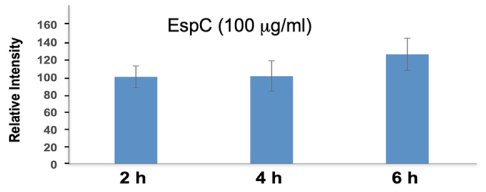

CspC $(100 \mu \mathrm{g} / \mathrm{ml})$

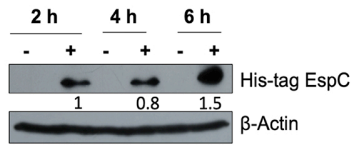


Fig. 5

A

EspC

EspB

PE35

EspF

EspJ

CFP10

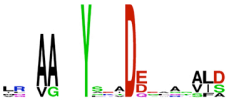

--TAGVDLAKSLRIAAKIYSEADEAWRKAIDGLFT

---------LRNAAKAYGEVDEEAATALDNDGEGTVQAESAGA---

---QLHRAGEAVQDVARTYSQIDDGAAGVFA---------------

--GVTSGLANNLLAAAGAYLKADDGLAGVIDKIFG----------

----------MNAAADVYAKTDQSLGTSLSQYAFGSSGEGLAGVASV

QKQELDEISTNIRQAGVQYSRADEEQQQALSSQMGF------------
B

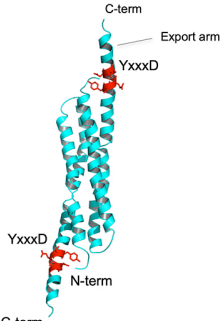

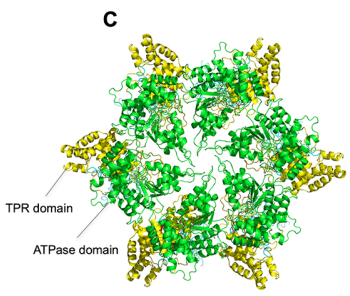



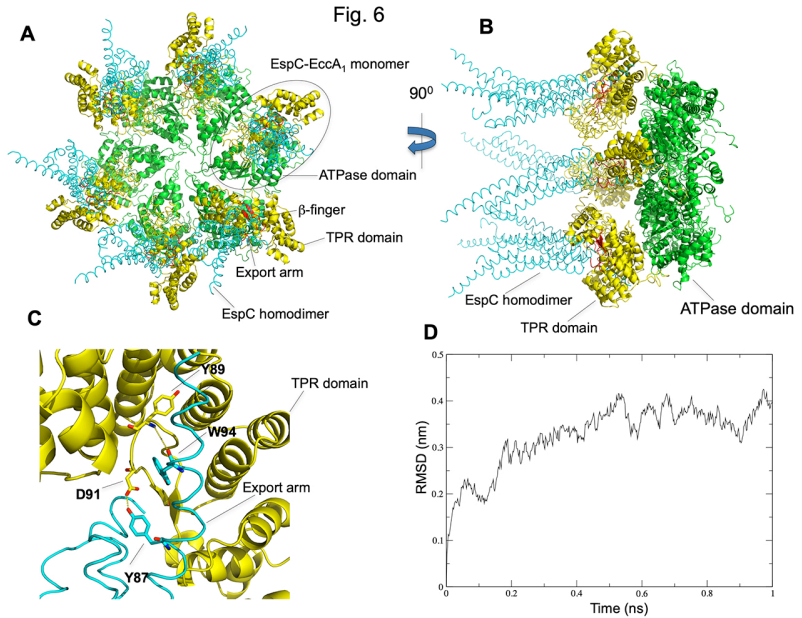


\section{Fig. 8}

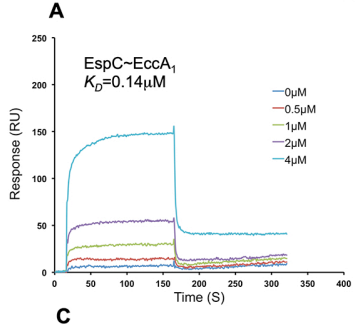

\section{B}
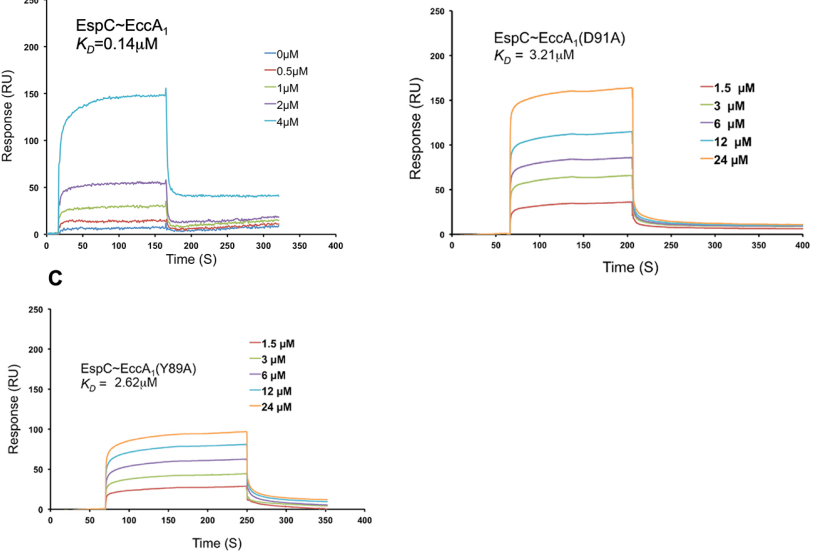


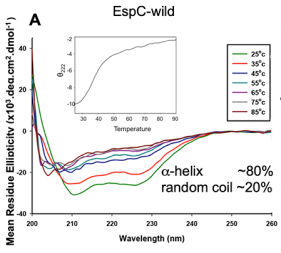

Fig. 9

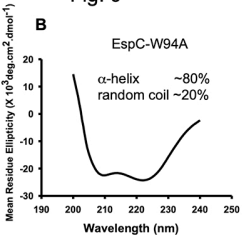

훙

C

लैं 20 EspC-Y87A

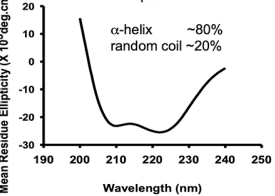

\section{EspC- $\Delta 5$ mutant}

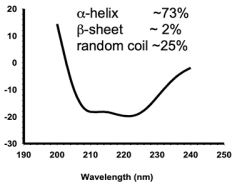

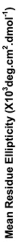

है

E EspC- $\Delta 10$ mutant

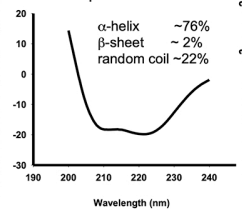

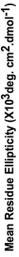

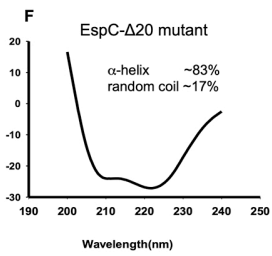


$\begin{array}{ll}\text { A } & \text { Fig. } 10\end{array}$
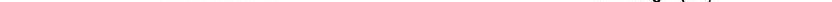